\section{Death and serious injury in child motorcyclists}

The increasing number of children aged under 16 years who have been injured while riding motorcycles has been called an epidemic. ${ }^{1}$ We report on 10 children admitted to hospital with serious injuries as a result of riding motorcycles and on another child who died before admission-the first death, to our knowledge, of a child motorcyclist reported in the United Kingdom.

\section{Patients, methods, and results}

The admission records of four Belfast teaching hospitals were examined for the period June 1984 to June 1985, and those of children aged under 16 who were admitted after a motorcycle accident were reviewed. The circumstances of each accident were determined and the injury severity score $^{2}$ calculated for each patient.

During the period under study one child died at the scene of the accident and 10 were admitted to hospital (table). There were 10 boys and one girl (age range 8-15 years). Nine children were injured between May and October, and six accidents occurred at weekends. The circumstances varied, but the most common feature (six cases) was loss of control by an inexperienced rider. The child who died rode into three strands of barbed wire stretched temporarily across a farm lane.

The injury severity score ranged from five to 34 (mean 13). There were seven major fractures of long bones, four of the femur, and three of the tibia and fibula. There were two blunt abdominal injuries, one resulting in a lacerated liver, managed by laparotomy and direct suture, and the other in renal contusion, managed conservatively. Five children suffered from closed head injuries of varying severity; all were successfully managed conservatively.

Details of accidents to children riding motorcycles, fune 1984 to fune 1985

\begin{tabular}{|c|c|c|c|c|}
\hline $\begin{array}{l}\text { Case } \\
\text { No }\end{array}$ & $\begin{array}{l}\text { Age (years)/ } \\
\text { sex }\end{array}$ & Circumstances & Injuries & $\begin{array}{l}\text { Injury } \\
\text { severity } \\
\text { score }\end{array}$ \\
\hline 1 & $15 M$ & $\begin{array}{l}\text { First ride on friend's } \\
\text { motorcycle }\end{array}$ & Fractured left femur & 10 \\
\hline $\begin{array}{l}2 \\
3\end{array}$ & $\begin{array}{l}14 M \\
14 M\end{array}$ & $\begin{array}{l}\text { Fell off motorcycle } \\
\text { Foot stuck under brake } \\
\text { pedal during motorcycle } \\
\text { race }\end{array}$ & $\begin{array}{l}\text { Facial laceration, head injury } \\
\text { Fractured right tibia and fibula }\end{array}$ & $\begin{array}{r}6 \\
10\end{array}$ \\
\hline 4 & $13 \mathrm{M}$ & $\begin{array}{l}\text { Throttle stuck on } 80 \mathrm{cc} \\
\text { motorcycle }\end{array}$ & Fractured shaft of left femur & 10 \\
\hline 5 & $11 \mathrm{M}$ & $\begin{array}{l}\text { Fell off three wheeled } \\
\text { motorcycle }\end{array}$ & $\begin{array}{l}\text { Head injury, facial lacerations, } \\
\text { fractured right tibia }\end{array}$ & 14 \\
\hline 6 & $10 \mathrm{M}$ & $\begin{array}{l}\text { Fell off motorcycle; bike } \\
\text { landed on top of him }\end{array}$ & Contused left kidney & 5 \\
\hline 7 & $10 \mathrm{M}$ & $\begin{array}{l}\text { Knocked off scrambler in } \\
\text { collision with another } \\
\text { motorcycle }\end{array}$ & Head injury, facial lacerations & 6 \\
\hline 8 & $10 \mathrm{~F}$ & First ride on tricycle & Compound fracture of left tibia & 10 \\
\hline 9 & $9 \mathrm{M}$ & $\begin{array}{l}\text { Lost control, fell off } \\
\text { motorcycle }\end{array}$ & Fractured left femur & 10 \\
\hline 10 & $9 M$ & $\begin{array}{l}\text { Junior scrambler ran into } \\
\text { barbed wire }\end{array}$ & $\begin{array}{l}\text { Garotted, ruptured larynx, } \\
\text { died }\end{array}$ & 25 \\
\hline 11 & $8 \mathbf{M}$ & $\begin{array}{l}\text { Collided with another bike } \\
\text { while scrambling in fields }\end{array}$ & $\begin{array}{l}\text { Head injury, contused lung, } \\
\text { lacerated liver, fractured } \\
\text { left femur }\end{array}$ & 34 \\
\hline
\end{tabular}

\section{Comment}

The increasing use of motorcycles by children is a recent phenomenon. Large companies that manufacture motorcycles market machines specifically for use by children, and many motorcycle clubs have junior sections that organise races for their young members. This increasing popularity has been associated with a rising toll of injury in the young. ${ }^{3}$

Previous studies have described a pattern of mainly minor injury. A recent two year prospective study from Oxford reported a mean injury severity score of only six, with a range from one to 14.4 This study had no fatalities, fewer cases of severe injury, fewer fractures of long bones, and no serious visceral injuries. Deaths and serious injuries similar to those in our study, however, have been reported by American workers. ${ }^{15}$

The main cause of these accidents is undoubtedly the inexperience of the rider. It is unfair, however, to blame the children, who are neither mentally mature enough to evaluate the risks nor physically mature enough to control a machine that is both heavy and powerful in relation to their physique. Parents who buy and manufacturers who make these machines shoulder the heavy responsibility for the inevitable injuries.

Motorcycle riding is an inappropriate form of recreation for young children, and an age limit is obviously required. A minimum age limit of 12 years could hardly be described as draconian, and yet if it were applied to this series seven accidents would have been avoided, including the one fatality and the two most serious injuries. For those children who do continue to ride motorcycles better instruction and supervision are urgently required. Parents, motorcycle dealers, and those who run the sport should be made aware of their responsibilities.

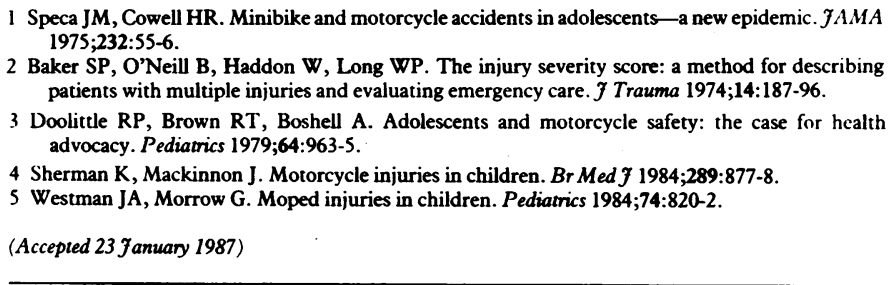

Department of Orthopaedic Surgery, Queen's University of Belfast, Musgrave Park Hospital, Belfast BT9 7SB

$S$ A HENDERSON, BSC, MB, senior house officer

H K GRAHAM, MD, FRCS, senior registrar

Royal Belfast Hospital for Sick Children, Belfast BT12 6BA

J PIGGOT, FRCs, consultant orthopaedic surgeon

Correspondence to: Dr S A Henderson, Department of Surgery, Queen's University of Belfast, Institute of Clinical Science, Belfast BT12 6BJ.

\section{Spinal injuries and BMX bicycles}

The child's bicycle has long been used as a form of transport, but recently it has become more of a toy. Many children own BMX bicycles, which are sturdy machines designed primarily for performing stunts off the road or for riding in trials. The increasing popularity of the BMX has been followed by an increase in injuries from cycling. ${ }^{2}$ Most injuries are minor and occur during riding off the road ${ }^{3}$; the most serious injuries tend to occur during road traffic accidents. ${ }^{\prime}$

We report two cases of paraplegia in children who lost control of BMX bicycles at high speed.

\section{Case reports}

Case 1-A 13 year old boy was riding his BMX bicycle at high speed down a steep hill on a normal metalled road. He lost control at a bend, hit the opposite kerb, and was thrown over the handlebars on to a fence. He became aware immediately of severe pain in his back and loss of use of his legs. He was found to have a fracture-dislocation of his thoracic spine at the T5 vertebra, with associated paraplegia and dense distal sensory loss. The fracture was treated with anterior spinal surgical stabilisation, and he attended a rehabilitation unit. There was no prospect of functional recovery from his spinal cord lesion.

Case 2-A 17 year old boy was riding his BMX bicycle at speed on a normal road. He lost control and collided with a stationary car, sustaining a fracturedislocation of the thoracolumbar junction with associated paraplegia and sensory loss. The fracture was stabilised posteriorly, and he attended a rehabilitation unit.

\section{Comment}

Considerable violence is required to cause a displaced spinal injury in the thoracic or thoracolumbar region. In the two cases reported here the injury was caused by loss of control of a BMX bicycle at high speed on a normal road. The riders were thrown over the handlebars, striking stationary objects. The average reported age for patients with injuries from BMX bicycles is about 10 years. ${ }^{1-3}$ Both of our patients were considerably older than this. Their added weight and strength would have helped them to achieve a greater velocity on the road, which would have increased the force of impact. The habit of treating the BMX bicycle as a toy persists when it is ridden on the road, often with less caution than road conditions merit.

Children are commonly thrown over the handlebars of BMX bicycles during accidents, an occurrence presumably facilitated by the design of the bicycle. The basic design allows good control at low speeds, but such control may be compromised during high speed manoeuvres.

It has been suggested that the BMX bicycle may be instrumental in 
reducing the incidence of serious injury by taking children off the road.' We agree that the place for the BMX bicycle is off the road, preferably on purpose built tracks. Appropriate training, supervision, and protective clothing should minimise the incidence of injury at low speed. Children riding on the public roads, however, must be encouraged to view BMX bicycles as a vulnerable form of transport.

1 Park KGM, Dickson AP. BMX bicycle injuries in children. Injury 1986;17:34-6.

2 Soysa SM, Grover ML, McDonald PJ. BMX bike injuries: the tatest epidemic. $\mathrm{Br}$ Med $\mathcal{J}$ 1984;289:960-1.

3 Illingworth CM. Injuries to children riding BMX bikes. Br Med f 1984;289:956-7.

(Accepted 23 fanuary 1987)

Department of Traumatic and Orthopaedic Surgery, Cardiff Royal Infirmary, Cardiff CF2 1SZ

S R JOHNSON, MB, FRCSED, registrar in orthopaedics

J A FAIRCLOUGH, MB, FRCS, senior registrar in orthopaedics

Correspondence to: $\mathrm{Mr}$ Johnson.

\section{Controlled trial of $\gamma$ linolenic acid in Dukes's C colorectal cancer}

Colorectal cancer is a common cause of death. This reflects the advanced stage of disease in many patients when the diagnosis is made and the limitations of treatment other than surgery. Cytotoxic drugs do not prevent relapse when given as an adjunct to surgery and do not increase the survival of patients with advanced disease. More effective forms of treatment are needed. Interest has been shown, at least by patients, in a nutritional approach to treatment, and there has been a drift towards centres for alternative treatment of cancer such as those in Bristol and Morecambe Bay, where diet plays a large part in the management programme. Controlled studies of dietary additives in the treatment of cancer have not, however, shown any benefit.

The diet used at the centre in Bristol includes a combination of $\gamma$ linolenic acid and vitamin $E$ (Efamol). $\gamma$ Linolenic acid, an oil extract of the seed from the evening primrose plant (Oenothera lamarckiana), is a polyunsaturated fatty acid from which prostaglandin $E_{1}$ is synthesised in a process requiring

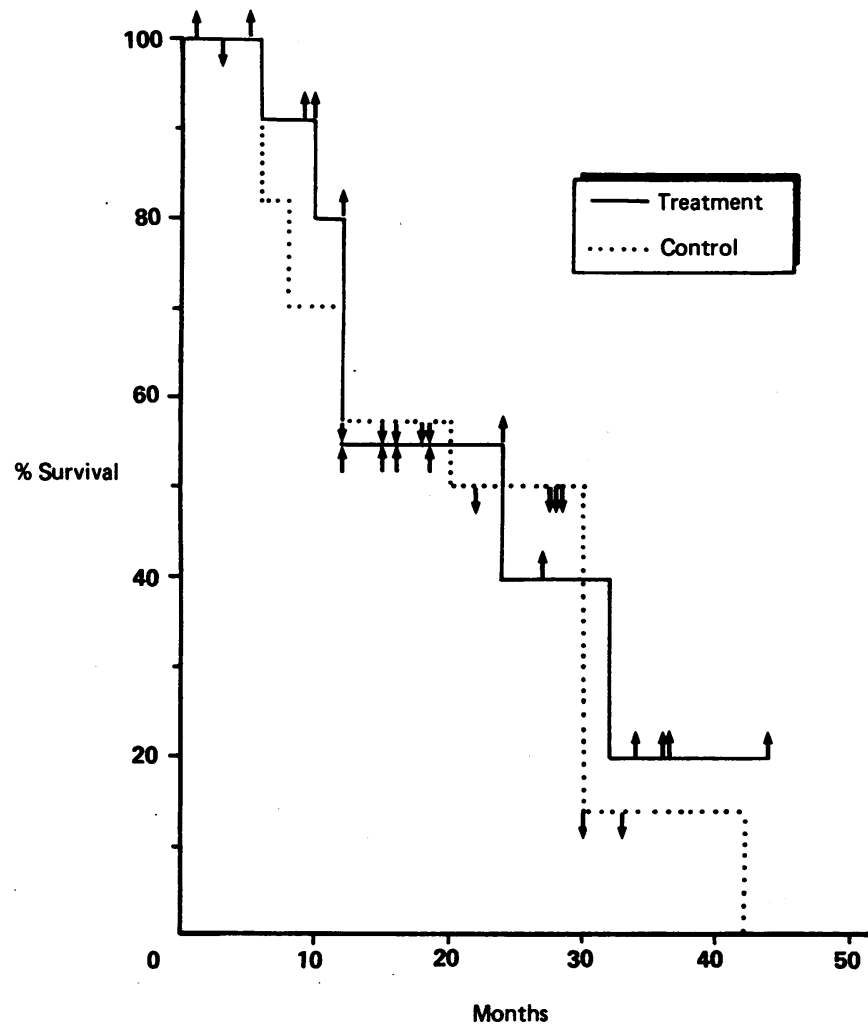

Survival in the two groups of patients. $\uparrow=$ Survivors among treated patients; $\downarrow=$ Survivors among controls. vitamin $C$, pyridoxine, and zinc. ${ }^{1}$ Prostaglandin $E_{1}$ can favourably affect the growth characteristics of animal and human tumour cells maintained in 0 culture. ${ }^{2}$

We have evaluated $\gamma$ linolenic acid in the treatment of colorectal cancer. The dose used was empirical but was considerably more than the dose suggested on theoretical grounds. ${ }^{2}$ We selected patients with Dukes's $C$ colorectal cancer because the residual tumour mass is small after operation, the relapse rate is high, and no other effective treatment is available. Moreover, metastases usually appear first in the liver and the highest concentration of $\gamma$ linolenic acid would be in the portal circulation, circumstances which should maximise any therapeutic effect.

\section{Patients, methods, and results}

Approval for the study was granted by the local district ethical committee, and informed consent was obtained from each patient. Patients with Dukes's $C$ colorectal cancer were assigned at random within one month of operation to receive Efamol capsules containing $\gamma$ linolenic acid $500 \mathrm{mg}$ and natural vitamin $\mathrm{E} \stackrel{\mathbb{Q}}{\mathcal{Q}}$ $10 \mathrm{mg}$ or capsules that were identical in appearance but contained an inert 2 placebo. Six capsules were given daily in divided doses for an indefinite period. All patients were also given six compound vitamin tablets daily each containing $\vec{\circ}$ vitamin C $125 \mathrm{mg}$, pyridoxine $25 \mathrm{mg}$, and zinc sulphate $5 \mathrm{mg}$. There were 54 patients in the study. All patients had normal serum carcinoembryonic antigen concentrations, and results of liver function tests were normal. None of the $\sigma$ patients had any evidence of metastatic disease before admission to the study. One patient stopped treatment after 12 months. Four patients failed to attend after admission to the study. Of the remaining 49 patients, 25 received $\gamma$ linolenic acid and vitamin $\mathrm{E}$ and 24 received placebo. Their mean ages were $62 \cdot 1$ years (range 48-81) and 64.8 years (range 45-77) respectively.

The figure shows the survival rate for the two groups. Ten patients in the $G$ treatment group died, with a median survival of 12 months (range 6-32); 12 N patients in the control group died, with a median survival of 12 months (range 6-42). In all cases death was due to local recurrent or metastatic liver disease or $N$ both; there was no difference in the pattern of disease in the two groups. No side 0 effects of treatment were noted apart from occasional facial flushing, which was attributed to pyridoxine. Twenty seven patients survived, with a median follow $\mathrm{O}$ up of 20 months (range 1 to 44 months) and 22 months (range 3 to 33 months) in the treatment and control groups, respectively.

\section{Comment}

A nutritional approach to treatment has been shown in limited studies to $₫$ have tumour regulating properties in some types of human cancer but not colorectal cancer. Thus $\gamma$ linolenic acid caused growth regression when added to cultured melanoma, hepatoma, osteogenic sarcoma, and oesophageal cells. ${ }^{3.5}$ Moreover, a striking reduction in liver size has been reported in patients with primary liver cancer taking $\gamma$ linolenic acid, and there is preliminary evidence of a response to $\gamma$ linolenic acid in patients with mesothelioma and astrocytoma (Abstract 161. Second congress of essential fatty acids, prostaglandins and leukotrienes, London 24-27 March, 1985). The mechanism is thought to be as follows: $\gamma$ linolenic acid can bypass the enzyme deficiency, common to cells of many tumour types, of $\delta-6$ desaturase, which normally converts dietary cis-linolenic acid to $\gamma$ linolenic acid, an essential step in the synthesis of prostaglandin $E_{1}$. This and other prostaglandins have antimetastatic actions and can initiate the process of reverse transformation of tumour cells in culture, thus probably having an important role in modulating cell behaviour. ${ }^{2}$

This is the first reported controlled clinical trial of $\gamma$ linolenic acid in human cancer and it has failed to show benefit in colorectal cancer.

We thank Efamol Ltd, Guildford, Surrey, for supplying the capsules containing $\gamma$ linolenic acid and vitamin $\mathrm{E}$ and the inert capsules.

Horrobin DF, Manku MS, Ota M. The nutiviona regulation of T lymphoc

Med Hypotheses 1979;5:969-85.
Horrobin DF. The reversibility of cancer: the relevance of cyclic AMP, calcium, essential fatty acids, and prostaglandin $\mathrm{E}_{1}$. Med Hypotheses 1980;6:469-86.

3 Dippenaar N, Booyens J, Fabbri D, Katzeff IE. The reversibility of cancer: evidence that malignancy in melanoma cells is gamma linolenic acid deficiency-dependent. $S$ Afr Med $\mathcal{J}$ 1982;62:505-9.

4 Dippenaar N, Booyens J, Fabbri D, Katzeff IE. The reversibility of cancer: evidence that malignancy in hepatoma cells is gamma linolenic acid deficiency-dependent. $S$ Afr Med $\mathcal{J}$ 1982;62:683-5.

Booyens J, Dippenaar N, Fabbri D. The effect of the prostaglandin precursor gamma-linolenic acid on the rate of proliferation of human osteogenic sarcoma and oesophageal carcinoma cells in culture. S Afr Med F 1984;65:240-2.

(Accepled 13 February 1987)

Royal Lancaster Infirmary, Lancaster LA1 4RR

M B MCILLMURRAY, DM, FRCP, consultant physician

W TURKIE, MB, MRCP, medical registrar

Correspondence to: Dr McIllmurray. 